\title{
Cloning and Expression of pca Genes from Pseudomonas putida in Escherichia coli
}

\author{
By E. JOHN HUGHES, $\dagger$ MARY K. SHAPIRO, JOHN E. HOUGHTON \\ AND L. NICHOLAS ORNSTON* \\ Department of Biology, Yale University, New Haven, CT 06511, USA
}

(Received 14 March 1988; revised 14 June 1988)

\begin{abstract}
$\beta$-Ketoadipate elicits expression of five structural $p c a$ genes encoding enzymes that catalyse consecutive reactions in the utilization of protocatechuate by Pseudomonas putida. Three derivatives of $P$. putida PRS2000 were obtained, each carrying a single copy of Tn5 DNA inserted into a separate region of the genome and preventing expression of different sets of pca genes. Selection of $\mathrm{Tn} 5$ in or near the $p c a$ genes in these derivatives was used to clone four structural pca genes and to enable their expression as inserts in pUC19 carried in Escherichia coli. Three of the genes were clustered as components of an apparent operon in the order pcaBDC. This observation indicates that rearrangement of the closely linked genes accompanied divergence of their evolutionary homologues, which are known to appear in the order pcaDBC in the Acinetobacter calcoaceticus pcaEFDBCA gene cluster. Additional evidence for genetic reorganization during evolutionary divergence emerged from the demonstration that the $P$. putida pcaE gene lies more than 15 kilobase pairs (kbp) away from the pcaBDC operon. An additional $P$. putida gene, $p c a R$, was shown to be required for expression of the pca structural genes in response to $\beta$-ketoadipate. The regulatory $p c a R$ gene is located about $15 \mathrm{kbp}$ upstream from the $p c a B D C$ operon.
\end{abstract}

\section{INTRODUCTION}

Six pca structural genes encode the enzymes that convert protocatechuate to citric acid cycle intermediates via the $\beta$-ketoadipate pathway (Fig. 1). The pathway is distributed widely among bacteria, and comparative studies indicate that structural genes for the pathway in biologically distant prokaryotic groups have evolved from a single ancestral set (Durham \& Ornston, 1980; Durham et al., 1980; Yeh et al., $1980 a, b$; Yeh \& Ornston, 1981). The divergent genes have fallen under different forms of transcriptional control (Canovas et al., 1967; Ornston \& Ornston, 1972; Stanier \& Ornston, 1973; Ornston \& Parke, 1977; Cain, 1980; Parke \& Ornston, 1986) and thus gene rearrangement appears to have played a significant role in the evolution of the pathway.

Recent investigations have established that genes for protocatechuate metabolism in Acinetobacter calcoaceticus, expressed coordinately in response to protocatechuate (Canovas \& Stanier, 1967), are clustered within a single transcriptional unit in the order pcaEFDBCA (Doten et al., 1987a; C. Hartnett, personal communication). Published evidence concerning the pca genes in Pseudomonas putida indicates that they are organized quite differently. The pcaA gene is the only $P$. putida gene expressed in response to protocatechuate, with $\beta$-ketoadipate eliciting expression of the other pca genes in this organism. The consequences of an apparent polarity mutation (Ornston, 1966) and frequent cotransduction of the $p c a B$ and $p c a D$ genes (Wheelis \& Stanier, 1970) suggested that $P$. putida genes are cotranscribed in the order $p c a B D C$. The inference that these genes formed a transcriptional unit was strengthened by the demonstration that regulatory mutations caused their constitutive expression (Parke \& Ornston, 1976).

+ Present address: Scully, Scott, Murphy \& Presser, 400 Garden City Plaza, Garden City, NY 11530, USA. 


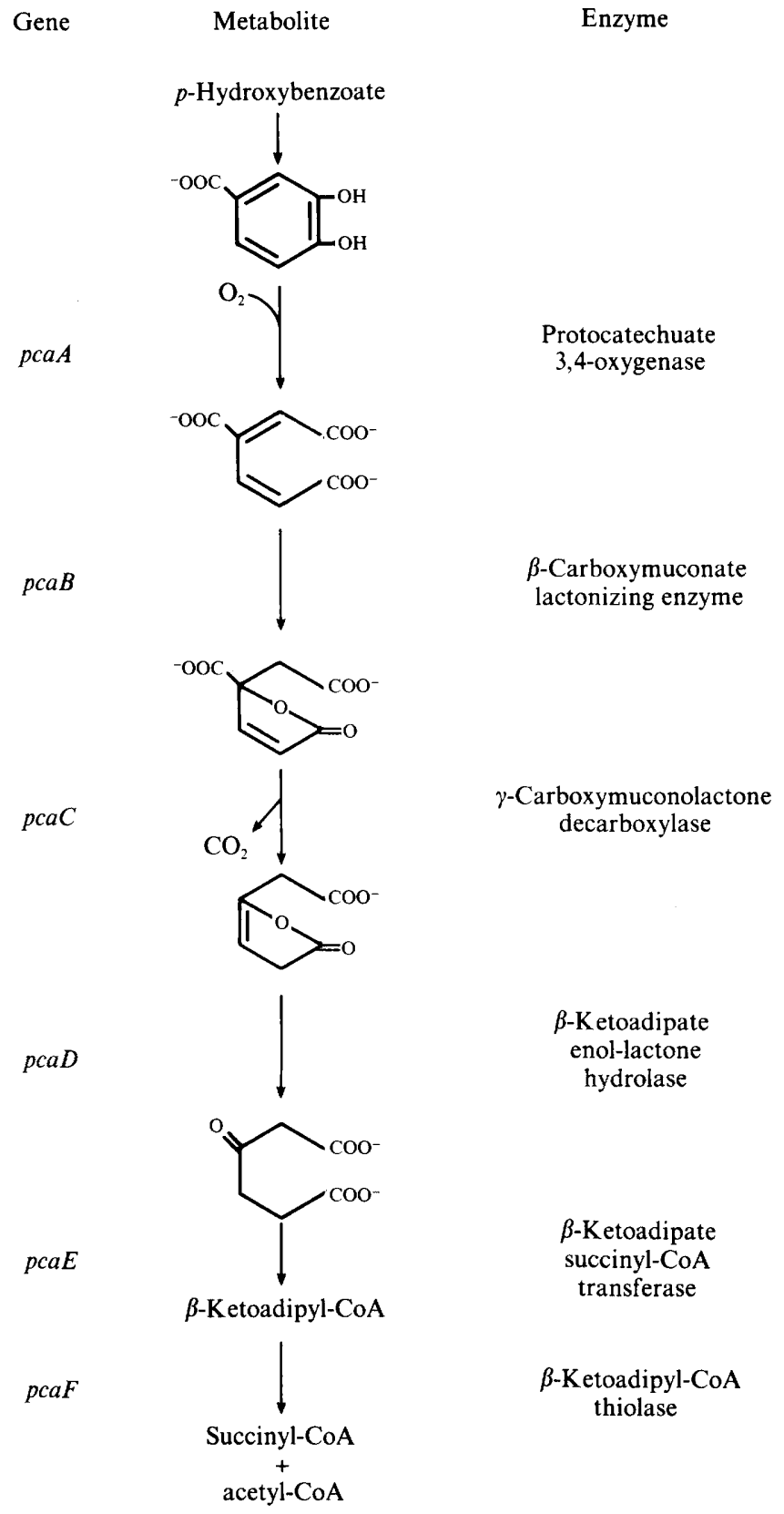

Fig. 1. Enzymes and structural genes associated with the central reactions of the $\beta$-ketoadipate pathway in $P$. putida.

Separate transcriptional control of the $p c a E$ gene was indicated by its inducible control in the constitutive pcaBDC mutant strains (Parke \& Ornston, 1976), yet this gene was cotransducible with genes from the $p c a B D C$ cluster in the wild-type strain (Wheelis \& Stanier, 1970).

In this article we describe the use of Tn 5 mutagenesis and subsequent cloning into Escherichia coli to elucidate the molecular organization of structural genes that respond to the inducer $\beta$-ketoadipate in $P$. putida. 
Table 1. Bacterial strains and plasmids

Strain or

plasmid

P. putida

PRS2000

PRS3004

PRS3015

PRS3016

E. coli

JM109

Necol00

Plasmids

pUC19

pRKTV14

pSUP1021

pPX40

pPX43

pPX44

pPX45

pPX53

pPX57

pPX81

pPX200

pPX202
Relevant genotype* or phenotype†

Wild-type

pcaE::Tn5 $\mathrm{Km}^{r} \mathrm{Pob}^{-} \mathrm{Ben}^{-}$

pcaR::Tn5 $\mathrm{Km}^{r} \mathrm{Pob}^{-} \mathrm{Ben}^{-}$

pcaB : :Tn5 $\mathrm{Km}^{r} \mathrm{Pob}^{-} \mathrm{Ben}^{-}$

recA endA gyrA96 thi hsdRI7 supE44 relA lac $Y$

(Alac-proAB) $\left[F^{\prime}\right.$ traD36 proAB lacI $I^{4}$ lacZ $\left.M 15\right]$

leu thr thi trp recA lac $Y$

Ap $\mathrm{lac} \mathrm{p} / \mathrm{o}$

$\mathrm{Sm}^{\mathrm{r}} \mathrm{Km}^{\mathrm{r}} \mathrm{Tn} 903:: \operatorname{Tn} 7:: \operatorname{Tn} 5$

$\mathrm{Te}^{\mathrm{r}} \mathrm{Km}^{\mathrm{r}} \mathrm{Cm}^{\mathrm{r}}$

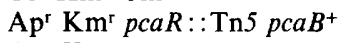

$\mathrm{Ap}^{r} \mathrm{Km}^{\mathrm{r}} \mathrm{pcaB}:: \operatorname{Tn} 5$ pcaC $\mathrm{C}^{+}$pcaD ${ }^{+}$

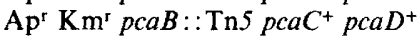

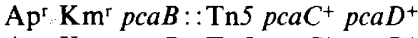

$\mathrm{Ap}^{\mathrm{r}} \mathrm{Km}^{\mathrm{r}} \mathrm{pcaB}:: \operatorname{Tn} 5 \mathrm{pcaC}^{+} p c a D^{+}$

$\mathrm{Ap}^{\mathrm{r}} \mathrm{pcaC^{+ }}$

$\mathrm{Ap}^{\mathrm{r}} p c a \mathrm{~B}^{+}$

$\mathrm{Ap}^{r} \mathrm{Km}^{r}$ pcaE $:: \operatorname{Tn} 5$

$\mathrm{Ap}^{\mathrm{r}} p c a E^{+}$
Source or referenceł

Parke \& Ornston (1976)

This study (PRS2000)

This study (PRS2000)

This study (PRS2000)

Yanisch-Perron et al. (1985)

Youvan et al. (1982)

Yanisch-Perron et al. (1985)

Gift from N. J. Panopoulos

Simon et al. (1986)

$17.7 \mathrm{kbp}$, partial SalI digest of PRS3015 $11.0 \mathrm{kbp}$, partial SalI digest of PRS3016 $4.8 \mathrm{kbp}$, partial SalI digest of PRS3016

$\sim 18 \mathrm{kbp}$, partial SalI digest of PRS3016

$\sim 13 \mathrm{kbp}$, EcoRI subclone of pPX43

$0.6 \mathrm{kbp}$, Sal I subclone of pPX44

$5.8 \mathrm{kbp}$, Sal I digest of PRS2000

$6.8 \mathrm{kbp}$, partial Sall digest of PRS 3004

$7.8 \mathrm{kbp}, E c o \mathrm{RI}$ digest of PRS2000

* Genetic designations in the text or in referenced text.

$\dagger \mathrm{Km}$, kanamycin; Ap, ampicillin; Sm, streptomycin; $\mathrm{Cm}$, chloramphenicol; Ben, benzoate; Pob, p-hydroxybenzoate.

$\ddagger k b p$, kilobase pairs, which refers to the size of the insert DNA fragment.

\section{METHODS}

Bacterial strains and plasmids. These are listed in Table 1. Strains of $P$. putida described herein were derived from the biotype A strain 90 (ATCC 12633) of Stanier et al. (1966). E. coli Necol00(pRKTV14) was kindly provided by N. Panopoulos (Youvan et al., 1982).

Media and growth conditions. P. putida and $E$. coli were grown at $30^{\circ} \mathrm{C}$ and $37^{\circ} \mathrm{C}$, respectively, in either L-broth (Miller, 1972) or defined mineral medium (Ornston \& Stanier, 1966) supplemented with Hutner's 'Metals 44' (Cohen-Bazire et al., 1957). When required, this medium was solidified using $1.5 \%(\mathrm{w} / \mathrm{v})$ Bacto-Agar. Unless otherwise specified, aromatic compounds were supplied at a concentration of $5 \mathrm{~mm}$ and nonaromatic compounds at $10 \mathrm{mM}$. All carbon sources were added aseptically to growth media immediately prior to inoculation. For enzyme analysis, $P$. putida strains were grown to late exponential phase in culture volumes of $200 \mathrm{ml}$ in one-litre Erlenmeyer flasks. Strains of $E$. coli were grown overnight in $50 \mathrm{ml}$ L-broth and then diluted fourfold with fresh Lbroth and incubated for a further $4 \mathrm{~h}$. When required, isopropyl $\beta$-D-thiogalactopyranoside (IPTG) was added to a final concentration of $1 \mathrm{~mm}$. Where indicated, kanamycin was added to media to a final concentration of $100 \mu \mathrm{g} \mathrm{ml}^{-1}$ for $P$. putida and $50 \mu \mathrm{g} \mathrm{ml}^{-1}$ for E. coli. Ampicillin was used at a final concentration of $50 \mu \mathrm{g} \mathrm{ml}^{-1}$. For preparation of chromosomal or plasmid DNA, cultures were grown in L-broth. In all cases, baffled shake flasks were used and aeration was achieved by shaking at 200 r.p.m. in a New Brunswick controlled-environment incubator.

Isolation of transposon Tn 5 insertion mutants. After overnight growth in L-broth, $0.1 \mathrm{ml}$ volumes of $E$. coli Necol00(pRKTV14) and P. putida PRS2000 were mixed on L-broth agar and grown overnight at $30^{\circ} \mathrm{C}$. The resulting growth was suspended in $5 \mathrm{ml}$ basal medium and plated onto basal medium containing $0.5 \mathrm{~mm}$-succinate, kanamycin, and either benzoate or $p$-hydroxybenzoate so as to give about 100 colonies per plate. Following incubation at $30^{\circ} \mathrm{C}$ for $3 \mathrm{~d}$, plates were examined for small colonies among a population of predominantly large colonies. Approximately $5-10 \%$ of the small colonies tested were unable to grow with the appropriate aromatic compound.

Enzyme assays. Procedures for preparation of extracts and enzyme assays have been described previously (Doten et al., 1987a). One unit of enzyme activity is defined as the amount of enzyme required to convert $1.0 \mu \mathrm{mol}$ substrate to product in $1 \mathrm{~min}$, under the assay conditions used. Protein concentrations were determined by the Lowry method. Indicator assays for detection of enol-lactone hydrolase, the $p c a D$ gene product, in whole cells have been described (Patel et al., 1975). 
Isolation of chromosomal and plasmid DNA. Chromosomal DNA was isolated by the method described by Berns \& Thomas (1965). Plasmid DNA was purified by the cleared lysate procedure (Schleif \& Wensink, 1981), using caesium chloride/ethidium bromide density gradient centrifugation.

In vitro DNA manipulation. Restriction endonuclease digestions were performed according to the manufacturer's specifications. For partial digestions, approximately $10 \mu \mathrm{g}$ chromosomal DNA was digested with 0.05 units of either $E c o \mathrm{RI}$ or $S a l \mathrm{I}$ for $1 \mathrm{~h}$ and mixed with $1 \mu \mathrm{g}$ of appropriately digested and dephosphorylated pUC19 plasmid DNA. The method used was that described by Maniatis et al. (1982).

DNA transformation. Transformation of $E$. coli was by the method of Hanahan (1983). The presence of recombinant plasmids was screened by identification of white colonies on agar plates containing L-broth, $0 \cdot 1 \mathrm{mM}-$ IPTG and $2 \%(\mathrm{w} / \mathrm{v})$ 5-bromo-4-chloro-3-indolyl $\beta$-D-galactopyranoside (X-Gal).

Analysis of recombinant plasmids. Southern hybridizations were performed according to established procedures (Southern, 1975). Purified DNA fragments were labelled by nick-translation with DNA polymerase and $\left[\alpha^{-32} \mathrm{P}\right] \mathrm{dTTP}$. The procedure of Maniatis $e t$ al. (1982) was used for colony DNA-DNA hybridization.

Chemicals and reagents. All chemicals used were of the highest quality available and, with the exception of $\beta$-carboxy-cis,cis-muconate (Meagher et al., 1972) and (+)-muconolactone (Ornston \& Stanier, 1966), were obtained commercially.

\section{RESULTS}

\section{Cloning and mapping of pcaE}

Transposon Tn5 insertion mutagenesis of $P$. putida strain PRS2000 yielded strain PRS3004, which was unable to grow at the expense of benzoate or $p$-hydroxybenzoate. Enzymic analyses revealed that this mutant strain expressed inducibly other structural genes of the $\beta$-ketoadipate pathway, but failed to express pcaE (Table 2).

No EcoRI restriction sites lie within Tn5, and restriction of PRS3004 chromosomal DNA with $E c o$ RI yielded a single $E c o$ RI restriction fragment that hybridized with DNA from Tn5 (Fig. 2, lane 2). Exposure of the mutant strain to $p$-hydroxybenzoate selected spontaneous revertants that invariably were kanamycin sensitive. Thus, strain PRS3004 appears to have acquired a single copy of $\mathrm{Tn} 5$ inserted in or near the pcaE structural gene.

Chromosomal DNA from strain PRS3004 was partially digested with SalI, ligated into pUC19 and transformed into E. coli strain JM109, followed by selection for kanamycin resistance. A selected strain carrying a $6.8 \mathrm{kbp}$ SalI insert in pUC19 was designated JM109(pPX200). The 6.8 kbp fragment was then used as a probe to screen an EcoRI-generated pUC19 genomic library of PRS2000 for clones containing DNA that hybridized with pcaE DNA. Approximately 5000 colonies were screened, and two hybridized strongly to the probe. After growth in the absence of IPTG, these strains expressed the pcaE gene at levels corresponding to $0.02 \mu \mathrm{mol} \mathrm{min}^{-1}$ (mg protein) $)^{-1}$. Addition of IPTG to the growth medium caused the cells to produce the pcaE gene product at levels ranging from 0.05 to $0.1 \mu \mathrm{mol} \mathrm{min}-1$ (mg protein) $)^{-1}$, indicating that the structural gene was under control of the lac

Table 2. Expression of pca genes in Tn5 derivatives of P. putida grown with glucose plus adipate

\begin{tabular}{|c|c|c|c|c|}
\hline \multirow[b]{2}{*}{ Strain } & \multicolumn{4}{|c|}{ Level of gene expression* } \\
\hline & pcaB & pcaC & $p c a D$ & $p c a E$ \\
\hline $\begin{array}{l}\text { PRS2000 } \\
\text { (wild-type) }\end{array}$ & $\begin{array}{c}100 \\
(0.98)\end{array}$ & $\begin{array}{c}100 \\
(3 \cdot 18)\end{array}$ & $\begin{array}{c}100 \\
(1 \cdot 54)\end{array}$ & $\begin{array}{c}100 \\
(0 \cdot 04)\end{array}$ \\
\hline $\begin{array}{l}\text { PRS3004 } \\
\quad(p c a E:: \operatorname{Tn} 5)\end{array}$ & 211 & 111 & 186 & $<1$ \\
\hline $\begin{array}{l}\text { PRS3015 } \\
\quad(p c a R:: \operatorname{Tn} 5)\end{array}$ & 12 & 13 & 9 & 5 \\
\hline $\begin{array}{l}\text { PRS3016 } \\
(p c a B:: \operatorname{Tn} 5)\end{array}$ & $<1$ & 20 & 8 & 183 \\
\hline
\end{tabular}

\footnotetext{
* Expressed as a percentage of the observed activity, relative to fully induced cells of wild-type $P$. putida grown in the presence of the gratuitous inducer, adipate. Experimental values of fully induced expression are given in parentheses as $\mu \mathrm{mol}$ substrate used or product formed $\min ^{-1}$ (mg protein) ${ }^{-1}$. The levels observed in strain PRS3015 after growth with glucose plus adipate were the same as those observed with uninduced wild-type cells.
} 


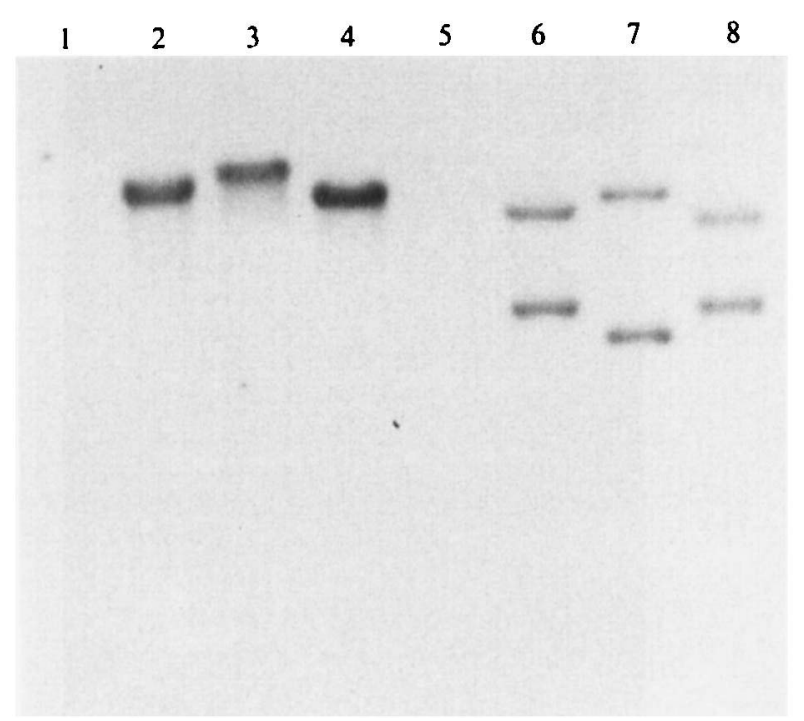

Fig. 2. Southern hybridization of chromosomal DNA from Tn 5 mutant strains of $P$. putida showing a single insertion of Tn 5 into the chromosome of each of the mutant strains. Lanes 1-4, DNA digested with EcoRI; lanes 5-8, DNA digested with SalI. Restricted DNA was electrophoresed on a $0.7 \%$ agarose gel and hybridized to the $2.7 \mathrm{kbp} \mathrm{BglII}$ fragment of Tn5. The $B g l$ II fragment was prepared from pSUP1021 and, after electrophoresis, isolated from low-melting-point agarose. Lanes 1 and 5 , PRS2000; lanes 2 and 6, PRS3004; lanes 3 and 7, PRS3015; lanes 4 and 8, PRS3016. EcoRI does not cut within $\mathrm{Tn} 5$ and gives rise to a single hybridizing band with $E c o$ RI-restricted DNA from strains carrying chromosomal Tn5 inserts. SalI cuts once within Tn5 and therefore gives rise to two hybridizing fragments with SalI-restricted DNA from the strains carrying Tn 5 inserts.

promoter. Expression of the $p c a E$ gene was not enhanced when adipate, a physiologically effective analogue of the inducer $\beta$-ketoadipate in $P$. putida (Parke \& Ornston, 1976), was included in the $E$. coli growth medium.

The plasmid from one of the strains was designated pPX202. Subsequent analysis of this plasmid indicated that it contained a single $7.8 \mathrm{kbp} \mathrm{EcoRI} \mathrm{insert} \mathrm{in} \mathrm{pUC19.} \mathrm{Cleavage} \mathrm{of} \mathrm{pPX202}$ with HindIII yielded 3.5 and $6.6 \mathrm{kbp}$ fragments. The latter contained pUC19 DNA and, upon ligation and introduction into $\mathrm{JM} 109$, did not express $p c a E$. The $3.5 \mathrm{kbp}$ insert also did not express pcaE when placed under the lac promoter of pUC19, and so it appears that the HindIII restriction site lies within the $p c a E$ gene. The $p c a E$ gene can be deduced to be about $1.2 \mathrm{kbp}$ in length (Yeh \& Ornston, 1981); the approximate location of the gene can be deduced as being within $1 \mathrm{kbp}$ of the HindIII site. All the subclones carrying each of the internal pPX202 SalI fragments inserted into pUC19 were prepared. None of the subclones expressed $p c a E$. Therefore it appears likely that the SalI site proximal to the HindIII site, which effectively bisects the pPX202 insert, also lies within the pcaE gene.

\section{Cloning and mapping of pcaB::Tn5, pcaC and pcaD}

Transposon Tn5 mutagenesis of $P$. putida PRS2000 gave rise to mutant strain PRS3016 which, in response to $\beta$-ketoadipate, was unable to express $p c a B$ but expressed slightly less than basal levels of $p c a C$ and $p c a D$. Under these conditions, pcaE was detected at levels comparable to those detected in PRS2000 which had been similarly induced. DNA isolated from PRS3016 yielded only one EcoRI fragment that hybridized with DNA from Tn5 (Fig. 2, lane 4). The basal levels of expression of the $p c a C$ and $p c a D$ genes are consistent with the genetic evidence provided by Wheelis \& Stanier (1970) which showed that $p c a B$ and $p c a D$ are tightly linked on the $P$. putida chromosome. These results would further suggest that this linkage is such that the three genes form a transcriptional unit and that the insertion of a single copy of $\operatorname{Tn} 5$ into or near the 


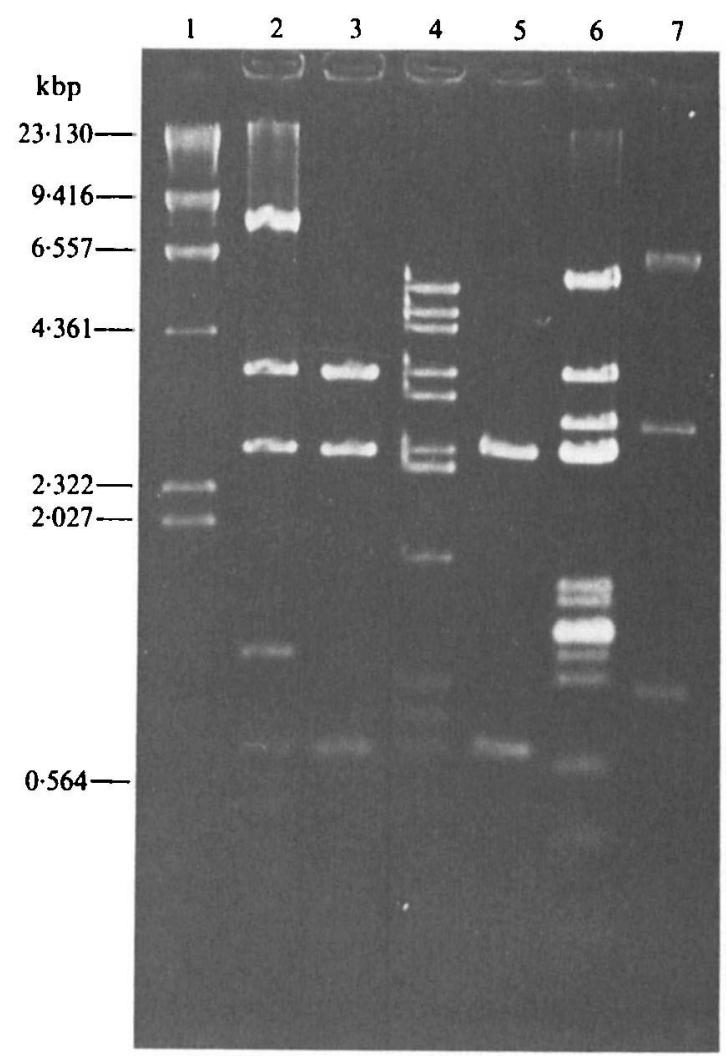

Fig. 3. Restriction endonuclease digestion of pca clones with SalI. Digested DNA was electrophoresed on a $0.7 \%$ agarose gel. Lane $1, \lambda$ DNA digested with HindIII (resulting in fragments of the sizes indicated); lane 2, pPX43; lane 3, pPX44; lane 4, pPX45; lane 5, pPX57; lane 6, pPX40; lane 7, pPX202.

$p c a B$ structural gene produced a polarity mutation reducing the expression of the neighbouring $p c a C$ and $p c a D$ genes. It would therefore appear likely that DNA bordering $p c a B:: \operatorname{Tn} 5$ might contain the pcaD gene. In order to explore this possibility, chromosomal DNA from strain PRS3016 was partially digested with Sall, ligated into pUC19 and transformed into E. coli strain JM109. Ten kanamycin-resistant colonies were isolated, three of which gave positive indicator tests for enol-lactone hydrolase, the product of the pcaD gene. Enzymic analysis of these three transformants, JM109(pPX43), JM109(pPX44) and JM109(pPX45), not only revealed expression of $p c a D$, but also of $p c a C$, both at levels comparable to those found in fully induced $P$. putida cultures. Adipate failed to influence the expression of either of the genes. Addition of IPTG to the growth medium increased expression of the genes approximately threefold, indicating that expression was being directed from the lac promoter. Although it is difficult to rationalize the expression of the plasmid-borne $p c a C$ and $p c a D$ genes in $E$. coli, it is possible that transcription from the lac promoter is sufficient to overcome the polarity mutation imposed by the $\operatorname{Tn} 5$ insertions. None of the $E$. coli transformants expressed any of the other pca structural genes.

Determination of the gene order pcaB::Tn5, pcaD, pcaC

Electrophoresis of $\mathrm{Sal}$ I digests of the aforementioned recombinant plasmids revealed that the respective inserts in pPX43, pPX44 and pPX45 are approximately $11 \mathrm{kbp}, 4.8 \mathrm{kbp}$ and $18 \mathrm{kbp}$ (Fig. 3). All three plasmids contain, in addition to the $2.7 \mathrm{kbp}$ pUC19 fragment, SalI segments 


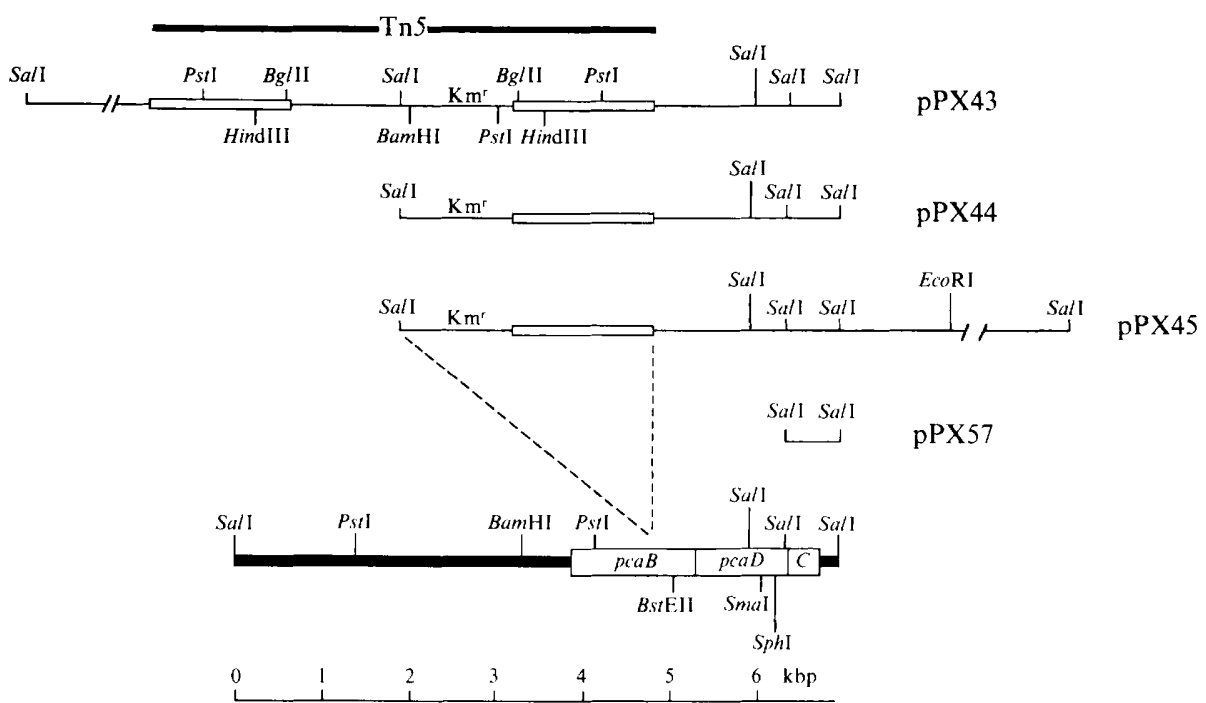

Fig. 4. Restriction and genetic map of the pcaBDC region of $P$. putida. Also shown are the relevant restriction maps of the pPX43, pPX44, pPX45 and pPX57 constructs, which depict the site of Tn5 insertion into $p c a B$ and their orientation with respect to the $p c a B D C$ region. Not shown in detail are the numerous $S a l \mathrm{I}$ restriction sites that border the $p c a B D C$ operon in plasmid pPX45. Transcription occurs from left to right, as determined by the lac promoter of pUC19.

of 3.8, 0.6 and $0.4 \mathrm{kbp}$ (Figs 3 and 4). A common terminus of the pPX44 and pPX45 segments at the internal Sal I site of Tn 5 was identified by demonstrating that they, unlike pPX43, lacked the characteristic internal $3.3 \mathrm{kbp}$ HindIII and $2.7 \mathrm{kbp} \mathrm{BglII}$ fragments that encompass the single SalI site within the transposon. Therefore, both the pPX44 and the pPX45 inserts contain at one end the portion of $\mathrm{Tn} 5$ beginning at the internal $\mathrm{Sal}$ I restriction site containing the kanamycin resistance gene (Fig. 4). The inserts extend $2 \cdot 1 \mathrm{kbp}$ and approximately $15 \mathrm{kbp}$, respectively, into $P$. putida DNA containing and lying beyond the $p c a C$ and pcaD genes.

Of the three inserts shared by pPX43, pPX44 and pPX45, the $3.8 \mathrm{kbp} \mathrm{SalI}$ fragment is the only one large enough to contain the kanamycin resistance gene of Tn5 (Fig. 3), and this fragment failed to express pcaC or pcaD when placed under the lac promoter of pUC19 in E. coli JM109. Thus it appeared that the SalI cuts giving rise to the $0.4 \mathrm{kbp}$ and $0.6 \mathrm{kbp}$ fragments inactivated or removed the two pca genes. Subsequent restriction analysis showed the sizes of the cloned $\mathrm{Sall}$ fragments to be in the order $3 \cdot 8,0.4$ and $0.6 \mathrm{kbp}$. The order of the genes was shown to be $p c a B, p c a D$, and $p c a C$ by subcloning the $0.6 \mathrm{kbp} \mathrm{SalI}$ fragment into pUC19. When carried in E. coli, the resulting plasmid, pPX57, expressed $p c a C$ at high levels but did not express pcaD. Thus the pcaC gene, which can be deduced to be approximately 0.4 kbp in size (Patel et al., 1975; Yeh et al., 1980a), lies within the $0.6 \mathrm{kbp} \mathrm{SalI}$ fragment.

\section{Cloning of pcaB}

The recombinant plasmid pPX43, containing the entire region of Tn5, was digested with $E c o$ RI, ligated into pUC19 and transformed into E. coli JM109 with selection for kanamycin resistance. Since $E c o$ RI cuts outside Tn5, we anticipated that plasmids in the resulting subclones would contain at least part of $p c a B:: \mathrm{Tn} 5$ in a region bordered by EcoRI restriction sites. One such subclone, carrying the plasmid designated pPX53, expressed high levels of $p c a C$ and $p c a D$ in response to induction by IPTG. No expression of these two genes was found in strains bearing recombinant plasmids in which the EcoRI fragment had been cloned in the reverse orientation.

Restriction analysis of pPX53 revealed that Tn 5 had inserted into a $5.8 \mathrm{kbp} \mathrm{SalI}$ fragment which presumably contained $p c a B$. The inserted EcoRI fragment from pPX53 was used to probe 
a Sal I-generated genomic DNA library of $P$. putida PRS2000 in E. coli JM109. Two of 7000 screened colonies contained DNA which hybridized to the EcoRI insert of pPX53. One of these strains, JM109(pPX81), containing only this $5.8 \mathrm{kbp} \mathrm{P}$. putida SalI fragment, expressed high levels of $p c a B$, but neither $p c a C$ nor $p c a D$. Restriction mapping showed that the $S a l I$ fragment in pPX81 was the same as that of pPX53 with the exception that the former did not contain Tn5 inserted into $p c a B$.

The restriction and genetic map of the $p c a B D C$ region is shown in Fig. 4. Not depicted fully on the map are $S a l$ I sites on the approximately $15 \mathrm{kbp}$ of $P$. putida DNA carried on pPX45 (Fig. 3). This DNA contains the portion of the $p c a B$ gene transcribed beyond its internal $S a l$ I restriction site, the $p c a D$ gene, the $p c a C$ gene, and about $13 \mathrm{kbp}$ of DNA extending downstream from this region. This DNA does not hybridize with the $7.8 \mathrm{kbp} E c o$ RI fragment containing the $p c a E$ gene (data not shown). Therefore we may conclude that the $p c a E$ gene does not lie in the region extending $15 \mathrm{kbp}$ downstream from the $p c a B D C$ cluster.

\section{Identification and mapping of the pcaR gene}

The initial screening of Tn5-inactivated mutants yielded one strain, PRS3015, that expressed low levels of $p c a E$ and basal levels of the $p c a B D C$ genes after growth in the presence of $p$-hydroxybenzoate. Expression of $p c a A$, induced by protocatechuate, was not affected in this strain. Adipate, an inducer of the $p c a B D C$ genes, the $p c a E$ gene and the cat genes in wild-type cells (Parke \& Ornston, 1976), elicited expression of the cat genes but not the pca genes in strain PRS3015 (Table 2). Therefore, the failure to express the pca genes cannot be attributed to a mutation blocking permeation of adipate into strain PRS3015. DNA from this strain produced only one EcoRI fragment that hybridized to Tn5 DNA (Fig. 2, lane 3), and thus the mutation in PRS3015 appeared to be a single insertion in a gene required for expression of the pca structural genes. Comparison of EcoRI and Sal I restriction fragments carrying Tn5 (Fig. 2) showed that the fragment containing the mutated gene, designated $p c a R$, is physically distinct from the respective EcoRI fragments containing the $p c a E$ gene and the $p c a B D C$ cluster.

Selection for growth with $p$-hydroxybenzoate gave rise to two classes of phenotypic revertants of strain PRS3015. Representatives of one class appeared to have lost the Tn5 insertion from $p c a R$ in that they were indistinguishable from wild-type cells with respect to both sensitivity to kanamycin and rate of growth with $p$-hydroxybenzoate. Representatives of the other class retained kanamycin resistance and formed small colonies on $p$-hydroxybenzoate. These strains expressed the pcaBDC genes at the basal level found in the parental strain PRS3015 and expressed constitutively the $p c a E$ gene at levels comparable to those found in fully induced wildtype $P$. putida cells. Thus mutations increasing expression of $p c a E$ seem to be sufficient to allow slow growth of $p c a R$ mutants with $p$-hydroxybenzoate.

Partial digestion of DNA from strain PRS3015 with SalI and subcloning of the resulting fragments yielded a pUC19 derivative, designated pPX40, that conferred kanamycin resistance and, in response to IPTG, expressed $p c a B$, but not $p c a D$ or $p c a C$, at levels comparable to those found in fully induced $P$. putida cultures. The other $p c a$ structural genes were not expressed from pPX40. In the absence of IPTG, E. coli JM109(pPX40) expressed pcaB at a low level which was not increased by addition of adipate to the growth medium.

Digestion of pPX40 with $B g l$ II and HindIII showed that it lacked the characteristic internal fragments of Tn5 and thus it appeared that the SalI segment at one end of the insert in this plasmid extends from the internal SalI site of the transposon through its kanamycin resistance marker and into P. putida DNA containing part of the pcaR gene. The identity of the SalI segment at the other end of the insert was indicated by the fact that SalI digests of the plasmid yielded the $5.8 \mathrm{kbp}$ fragment that carries the $p c a B$ gene but did not produce the 0.4 and $0.6 \mathrm{kbp}$ SalI fragments associated with the $p c a D$ and $p c a C$ genes. Other fragments produced by digestion of pPX40 with SalI account for approximately $15 \mathrm{kbp}$ of $P$. putida DNA that lies between $p c a R:: \operatorname{Tn} 5$ and $p c a B$. This DNA does not hybridize with the $7.8 \mathrm{kbp} E c o$ RI fragment containing the $p c a E$ gene (data not shown). It therefore appears that $p c a E$ is not in the region extending $15 \mathrm{kbp}$ upstream from pcaB. 


\section{DISCUSSION}

\section{Organization of pca structural genes}

The conclusion that the $P$. putida pca genes form a transcriptional unit in the order $p c a B D C$ is in accord with earlier observations of polar expression (Ornston, 1966), unified transcriptional control (Parke \& Ornston, 1976) and genetic linkage (Wheelis \& Stanier, 1970). The sizes of the $S a l$ restriction fragments produced from the plasmid pPX44 indicate that a portion of the pcaB gene, the $p c a D$ gene and the $p c a C$ gene are encompassed in no more than $2.1 \mathrm{kbp}$ of DNA. The sizes of the products of the latter two genes (Parke, 1979; Yeh \& Ornston, 1981; Yeh et al., $1980 \mathrm{a}$ ) indicate that they require at least $1.4 \mathrm{kbp}$ of DNA sequence, so it is reasonable to conclude that the three genes are closely clustered. Amino acid sequence comparisons have shown that pcaD (Yeh et al., 1980b) and pcaC (Yeh et al., 1980a) genes from P. putida are homologous with their counterparts from $A$. calcoaceticus, and therefore it is remarkable that, in the latter species, the $p c a B, p c a D$ and $p c a C$ genes are tightly linked in a different sequence as part of an operon transcribed in the order pcaEFDBCA (Doten et al., 1987a; C. Hartnett, personal communication). Evidently gene rearrangements exceeded those demanded for the different transcriptional controls exercised over $p c a$ genes in the two bacterial species.

The results of this investigation indicate that the $p c a E$ structural gene lies more than $15 \mathrm{kbp}$ from the $p c a B D C$ operon on $P$. putida. These findings reduce, but do not eliminate, ambiguities that emerged from an earlier investigation of the linkage of $p c a B$ and $p c a E$ in $P$. putida. A single $p c a B$ donor yielded respective cotransduction frequencies of $13 \%$ and $69 \%$ when tested with two different pcaE recipients (Wheelis \& Stanier, 1970). The $p c a E$ gene product is composed of two different protein subunits (Yeh \& Ornston, 1981), and one interpretation to account for the discrepancy in transduction frequencies is that the recipients carried mutants in physically distant structural genes for the two different subunits. This interpretation is rendered unlikely by our observation that the $p c a E$ gene can be expressed in its entirety from a single $7.8 \mathrm{kbp}$ restriction segment.

Wheelis \& Stanier (1970) suggested that many of the ambiguities observed in transductional analysis of $P$. putida pca genes and neighbouring genes could be resolved by construction of a circular map. At face value, this interpretation might seem to be inconsistent with the genes residing as components of a linear chromosome. A possible resolution of this inconsistency might lie in physical interactions among DNA sequences that are distant in primary structure. Such interactions might lead to relatively frequent packaging of two separate DNA segments in the same transducing phage coat. Evidence that unlinked genes may interact is given by demonstration of repair of a pcaE mutation by cat BCE sequences in $A$. calcoaceticus (Doten et al., 1987b).

\section{Transcriptional control exerted by pcaR in P. putida}

The $p c a R$ regulatory gene, which has been found to lie approximately $15 \mathrm{kbp}$ upstream from the pcaBDC operon, is required for expression of physically separate genes transcribed by different promoters that respond inducibly to $\beta$-ketoadipate in $P$. putida. Earlier evidence for different promoters, such as the constitutive expression of the pcaBDC genes in mutants that remained inducible for $p c a E$ (Parke \& Ornston, 1976), is fortified by our finding that mutations causing enhanced transcription of $p c a E$ did not influence expression of the $p c a B D C$ cluster. Benzoate chemotaxis, an additional inducible response to ketoadipate (Harwood et al., 1984), is lost as a consequence of the pcaR mutation in P. putida (C. Harwood, personal communication). Therefore the $p c a R$ gene may exert positive control over a number of different transcriptional units in P. putida.

Several taxa deserve special attention in comparative studies directed at the elucidation of processes underlying divergence of the $p c a R$ regulatory gene. Pseudomonas aeruginosa resembles $P$. putida in many respects and elaborates closely homologous structural genes (Patel \& Ornston, 1976) that appear to be organized and transcribed in a roughly similar fashion (Kemp \& Hegeman, 1968). Azotobacter species possess pca structural genes that are homologous to their $P$. putida counterparts, and $\beta$-ketoadipate elicits a similar inducible response in these two 
biological groups (Durham \& Ornston, 1980). Therefore it will be of interest to determine if homologues of pcaR govern gene expression in Azotobacter. Benzoate is not metabolized via $\beta$-ketoadipate in Azotobacter (Hardisson et al., 1969; Sala-Trepat \& Evans, 1971), and it will be interesting to determine how benzoate chemotaxis, if it is demonstrated by members of this genus, is controlled. $\beta$-Ketoadipate serves no known function as an inducer in Acinetobacter calcoaceticus, and it seems reasonable to propose that representatives of this species do not contain a functional counterpart of $p c a R$.

\section{REFERENCES}

Berns, K. I. \& Thomas, C. A., JR (1965). Isolation of high molecular weight DNA from Haemophilus influenzae. Journal of Molecular Biology 11, 476-490.

CAIN, R. B. (1980). The uptake and catabolism of lignin-related aromatic compounds and their regulation in microorganisms. In Lignin Biodegradation: Microbiology, Chemistry and Potential Applications, vol. 1, pp. 21-60. Edited by T. Kent Kirk, T. Higuchi \& H. Chang. Boca Raton, Florida: CRC Press.

Canovas, J. L. \& Stanier, R. Y. (1967). Regulation of the enzymes of the $\beta$-ketoadipate pathway in Moraxella calcoaceticus. European Journal of Biochemistry 1, 289-300.

Canovas, J. L., Ornston, L. N. \& Stanier, R. Y. (1967). Evolutionary significance of metabolic control systems. Science 156, 1695-1699.

Cohen-Bazire, G., Sistrom, W. R. \& Stanier, R. Y. (1957). Kinetic studies of pigment synthesis by nonsulfur purple bacteria. Journal of Comparative and Cellular Physiology 49, 25-68.

Doten, R. C., Ngai, K.-L., Mitchell, D. J. \& ORNStON, L. N. (1987a). Cloning and genetic organization of the pca gene cluster from Acinetobacter calcoaceticus. Journal of Bacteriology 169, 3168-3174.

Doten, R. C., Gregg, L. A. \& Ornston, L. N. $(1987 b)$. Influence of the catBCE sequence on the phenotypic reversion of a pcaE mutation in Acinetobacter calcoaceticus. Journal of Bacteriology 169, 3175-3180.

Durham, D. R. \& ORnSton, L. N. (1980). Homologous structural genes and similar induction patterns in Azotobacter and Pseudomonas. Journal of Bacteriology 143, 834-840.

Durham, D. R., Stirling, L. A., ORnston, L. N. \& PERRY, J. J. (1980). Intergeneric evolutionary homology revealed by the study of protocatechuate 3,4-dioxygenase from Azotobacter vinelandii. Biochemistry 19, 149-155.

HaNAHAN, D. (1983). Studies on transformation of Escherichia coli with plasmids. Journal of Molecular Biology 166, 557-580.

Hardisson, C., Sala-Trepat, J. M. \& Stanier, R. Y. (1969). Pathways for the oxidation of aromatic compounds by Azotobacter. Journal of General Microbiology 59, 1-11.

HaRwood, C. S., Rivelli, M. \& Ornston, L. N. (1984). Aromatic acids are chemoattractants for Pseudomonas putida. Journal of Bacteriology 160, 622-628.

Kemp, M. B. \& Hegeman, G. D. (1968). Genetic control of the $\beta$-ketoadipate pathway in Pseudomonas aeruginosa. Journal of Bacteriology 96, 14881499.

Maniatis, T., Fritsch, E. F. \& Sambrook, J. (1982). Molecular Cloning: a Laboratory Manual. Cold Spring Harbor, NY: Cold Spring Harbor Laboratory.

Meagher, R. B., McCorkle, G. M. \& Ornston, L. N. (1972). Inducible uptake system for $\beta$-carboxycis, cis-muconate in a permeability mutant of Pseudomonas putida. Journal of Bacteriology 111, 465-473.

Miller, J. H. (1972). Experiments in Molecular Genetics. Cold Spring Harbor, NY: Cold Spring Harbor Laboratory.

ORNSTON, L. N. (1966). The conversion of catechol and protocatechuate to $\beta$-ketoadipate by Pseudomonas putida. IV. Regulation. Journal of Biological Chemistry 241, 3800-3810.

Ornston, M. K. \& Ornston, L. N. (1972). The regulation of the $\beta$-ketoadipate pathway in Pseudomonas acidovorans and Pseudomonas testosteroni. Journal of General Microbiology 73, 455-464.

ORnston, L. N. \& PARKe, D. (1977). The evolution of induction mechanisms in bacteria: insights derived from study of the $\beta$-ketoadipate pathway. Current Topics in Regulation 12, 209-262.

Ornston, L. N. \& Stanier, R. Y. (1966). The conversion of catechol and protocatechuate to $\beta$ ketoadipate by Pseudomonas putida. I. Biochemistry. Journal of Biological Chemistry 241, 3776-3786.

PARKE, D. (1979). Structural comparison of gammacarboxymuconolactone decarboxylase and muconolactone isomerase from Pseudomonas putida. Biochimica et biophysica acta 578, 145-154.

PARKe, D. \& ORNSTON, L. N. (1976). Constitutive synthesis of enzymes of the protocatechuate pathway and of the $\beta$-ketoadipate uptake system in mutant strains of Pseudomonas putida. Journal of Bacteriology 126, 272-281.

PARKe, D. \& ORnSTON, L. N. (1986). Enzymes of the $\beta$-ketoadipate pathway are inducible in Rhizobium and Agrobacterium spp. and constitutive in Bradyrhizobium spp. Journal of Bacteriology 165, 288-292.

PATEL, R. N. \& ORNSTON, L. N. (1976). Immunological comparison of enzymes of the $\beta$-ketoadipate pathway. Archives of Microbiology 110, 27-36.

Patel, R. N., Mazumdar, S. \& Ornston, L. N. (1975). $\beta$-Ketoadipate enol-lactone hydrolases I and II from Acinetobacter calcoaceticus. Journal of Biological Chemistry 250, 6567-6577.

Sala-Trepat, J. M. \& Evans, W. C. (1971). The meta cleavage of catechol by Azotobacter sp.: 4-oxalocrotonate pathway. European Journal of Biochemistry 20, 400-413.

.SChleif, R. F. \& Wensink, P. C. (1981). Practical Methods in Molecular Biology. New York: Springer. 
Simon, R., O'Connell, M., Labes, M. \& Puhler, A. (1986). Plasmid vectors for the genetic analysis and manipulation of rhizobia and other gram-negative bacteria. Methods in Enzymology 118, 640-659.

Southern, E. M. (1975). Detection of specific sequences among DNA fragments separated by gel electrophoresis. Journal of Molecular Biology 98, 503-517.

Stanier, R. Y. \& Ornston, L. N. (1973). The $\beta$ ketoadipate pathway. Advances in Microbial Physio$\log y$ 9, 89-151.

Stanier, R. Y., Palleroni, N. J. \& Doudoroff, M. (1966). The aerobic pseudomonads: a taxonomic study. Journal of General Microbiology 43, 159-271.

WheElis, M. L. \& Stanier, R. Y. (1970). The genetic control of dissimilatory pathways in Pseudomonas putida. Genetics 66, 245-266.

Yanisch-Perron, C., Vieira, J. \& Messing, J. (1985). Improved M13 cloning vectors and host strains: nucleotide sequences of the M13mp.18 and pUC19 vectors. Gene 33, 103-119.
YEH, W. K. \& ORnston, L. N. (1981). Evolutionarily homologous $\alpha_{2} \beta_{2}$ oligomeric structures in $\beta$-ketoadipate succinyl CoA transferases from Acinetobacter calcoaceticus and Pseudomonas putida. Journal of Biological Chemistry 256, 1565-1569.

YeH, W. K., Fletcher, P. \& ORNSTON, L. N. (1980a). Evolutionary divergence of co-selected $\beta$-ketoadipate enol-lactone hydrolases in Acinetobacter calcoaceticus. Journal of Biological Chemistry 255, 63426346.

YeH, W. K., Fletcher, P. \& ORnSton, L. N. (1980 $b$ ). Homologies in the $\mathrm{NH}_{2}$-terminal amino acid sequence of gamma-carboxymuconolactone decarboxylases and muconolactone isomerases. Journal of Biological Chemistry 255, 6347-6354.

Youvan, D. C., Elder, J. T., Sandlin, D. E., Zsebo, K. M., Alder, D. P., Panopoulos, N. J., Marrs, B. L. \& HeARST, J. E. (1982). R-prime site directed transposon mutagenesis of the photosynthetic apparatus in Rhodopseudomonas capsulata. Journal of Molecular Biology 162, 17-41. 